\title{
Optimization of RP-HPLC method with UV detection for determination of ursodeoxycholic acid in pharmaceutical formulations
}

\author{
Zhaklina Poposka Svirkova ${ }^{1}$, Zorica Arsova-Sarafinovska ${ }^{1}$, \\ Aleksandra Grozdanova ${ }^{2}$ \\ ${ }^{1}$ Institute for Public Health of the Republic of North Macedonia, St. 50 Division No.6, \\ 1000 Skopje, Republic of North Macedonia \\ ${ }^{2}$ Instute of Pharmaceutical Chemistry, Faculty of Pharmacy, \\ Ss. Cyril and Methodius University, Majka Tereza 47, 1000 Skopje, \\ Republic of North Macedonia
}

Received: November 2019; Accepted: December 2020

\begin{abstract}
Due to the low absorptivity of bile acids, the aim of this study was to develop and validate a simple and sensitive HPLC/UV method for quantification of ursodeoxycholic acid (UDCA) in pharmaceutical formulations. Effective separation was achieved on C18 endcapped column, with gradient elution of a mobile phase composed of $0.001 \mathrm{M}$ phosphate buffer $(\mathrm{pH} 2.8 \pm 0.5)$ - acetonitrile mix, at flow rate $1.5 \mathrm{~mL} \mathrm{~min}^{-1}$, UV detection at $200 \mathrm{~nm}$ and injection volumes were $50 \mu \mathrm{L}$. The proposed HPLC method was fully validated according to the ICH guidelines and it was found to be simple, accurate, precise and robust.
\end{abstract}

Keywords: ursodeoxycholic acid, HPLC/UV, pharmaceutical formulations, validation

\section{Introduction}

Bile acids are natural products i.e. they are terminal endogenous catabolism products of cholesterol and play a crucial role in cholesterol homeostasis, lipid absorption and production of bile flow. According to their origins, bile acids can be divided into primary and secondary (Qiao et al., 2012). Primary bile acids are cholic acid (CA) and chenodeoxycholic acid (CDCA), while deoxycholic acid (DCA) and lithocholic acid (LA) are secondary bile acids. In addition, CDCA is partially epimerized into tertiary bile acid called ursodeoxycholic acid (UDCA), which represents a group of "minor" bile bile acids that have significant importance (Stamp and Jenkins, 2008). UDCA is a known, safe and efficacious drug that has been widely used for oral gallstone dissolution therapy (Mas et al., 2007).

The IUPAC chemical name of UDCA is $3 \alpha, 7 \beta-$ dihydroxy-5 $\beta$-cholan-24-oic acid, with an empirical formula $\mathrm{C}_{24} \mathrm{H}_{40} \mathrm{O}_{4}$ and a molecular weight of 392.64 $\mathrm{g} / \mathrm{mol}$. It has an appearance of white powder with a bitter taste. It is freely soluble in ethanol and glacial acetic acid, slightly soluble in chloroform, sparingly soluble in ether, and practically insoluble in water, with $\mathrm{pKa} \sim 4.66$ (Soni Varinder et al., 2015a). UDCA (7 $\beta$-position) is an epimer of CDCA ( $7 \alpha$-position) and due to this structural modification, is less hydrophobic, detergent and toxic bile acid. (Roda et al., 1995).

\footnotetext{
*zpoposka2012@gmail.com
} 
The USP and $\mathrm{Ph}$. Eur. official monographs refer to an HPLC method with a refractive index detector or a TLC method for the analysis of UDCA in raw materials. In literature, there are other methods described for determination of UDCA, such as: HPLC methods coupled to MS (Raghunadha Reddy, 2010) and evaporative lightscattering mass detection (Roda et al., 1992), GC methods coupled to MS (Courillon et al., 1997), and capillary electrophoresis method or micellar electrokinetic chromatography (Rodríguez et al., 2000). However, these methods require a high sample amount and the instruments required are not a common laboratory equipment.

To the best of our knowledge, for determination of UDCA in raw material and pharmaceuticals the application of UV detector is limited due to the low absorptivity of bile acids. Therefore, the aim of our work was to develop and validate a simple and sensitive HPLC/UV method for quantification of UDCA in solid pharmaceutical formulations that could be applied in quality control laboratories.

\section{Materials and methods}

\section{Chemicals, reagents and HPLC instrumentation}

UDCA, CA, CDCA and LA standard substances, used in the study, were provided by EDQM. The pharmaceutical dosage forms, hard capsules containing UDCA (150 mg/capsule), were obtained from the commercial market. Acetonitrile and methanol were HPLC-grade, and purchased from Merck (Darmstadt, Germany). Phosphoric acid, potassium phosphate monobasic anhydrous and formic acid were supplied from Sigma-Aldrich (St. Louis, MO, USA). Double-distilled water was used to prepare mobile phase solutions. All solutions were filtered through a $0.45 \mu \mathrm{m}$ (pore size) nylon membrane filter and vacuum degassed before use.

HPLC analyses were performed using a Schimadzu LC-2010 chromatographic system (Schimadzu, Kyoto, Japan). Chromatograms were processed using Class VP 7.3 Software.

\section{Chromatographic Conditions}

Effective chromatographic separation was achieved using a LiChroCART ${ }^{\circledR}$ Purospher ${ }^{\circledR}$ STAR RP-18 endcapped column ( 150 x $4.6 \mathrm{~mm}$ i.d., particle size $5 \mu \mathrm{m})$ as stationary phase with gradient elution of a mobile phase composed of $0.001 \mathrm{M}$ potassium phosphate buffer (adjusted to $\mathrm{pH} 2.8 \pm 0.5$, using phosphoric acid) and acetonitrile $(\mathrm{ACN})$. A linear gradient was used (0-35 min, 40-80\% ACN; 35-35.01 min, 80-40\% ACN; and 35.01$41 \mathrm{~min}, 40 \% \mathrm{ACN})$. The column temperature was maintained at $40{ }^{\circ} \mathrm{C}$. The flow rate was $1.5 \mathrm{~mL} \mathrm{~min}^{-1}$ and the detection wavelength was set at $200 \mathrm{~nm}$. The injection volumes were $50 \mu \mathrm{L}$.

\section{Preparation of solutions}

Standard Mix Solution (target working concentration of $0.6 \mathrm{mg} \mathrm{mL}^{-1}$ of all bile acids standards, UDCA, CA, CDCA and LA) was prepared by transferring $2 \mathrm{~mL}$ from each stock standard solution to a $10 \mathrm{~mL}$ volumetric flask and diluting with a same dilution solvent up to mark. Stock standard solutions were prepared by dissolving UDCA, CA, CDCA and LA (30 mg) consequently with $10 \mathrm{~mL}$ dilution solution.

As dilution solvent was used an acidified methanol with $0.05 \%$ formic acid (in a ratio of $75: 25, v / v$ ), $\mathrm{pH} 3.0$ of solution.

Sample solution was prepared as follows: twenty capsules containing $150 \mathrm{mg}$ UDCA were weighed accurately, the capsule content was mixed, homogenized and a capsule powder equivalent to $150 \mathrm{mg}$ UDCA was used and diluted with dilution solvent to obtain a working concentration of $0.6 \mathrm{mg} \mathrm{mL} \mathrm{mLCA}^{-1}$ UDC. Sample solution was filtered through a membrane filter $0.45 \mu \mathrm{m}$ (pore size) prior to injecting into the HPLC system.

\section{Results and discussion}

In order to establish an efficient, selective and fit for purpose analytical method with optimum resolution between UDCA, related substances and excipients, several method variables were employed, such as use of different HPLC columns, different compositions and $\mathrm{pH}$ of mobile phase, and different concentrations of standard and sample solutions. We used HPLC RP-18 columns from different manufacturers with various lengths $(25.0,15.0,12.5$ and $10.0 \mathrm{~cm}$ ) and constant internal diameter of $4.6 \mathrm{~mm}$, but we obtained a poor peak shape. Finally, a LiChroCART ${ }^{\circledR}$ Purospher ${ }^{\circledR}$ STAR RP - 18 end-capped column, 150 x $4.6 \mathrm{~mm}$ i.d., particle size $5 \mu \mathrm{m}$ (Merck, Germany) was chosen for the study as an excellent peak shape was obtained. Column temperature was maintained at $40{ }^{\circ} \mathrm{C}$.

Acetonitrile was chosen in the mobile phase because of its absorbance (UV cut off) at low wavelengths, while a phosphate buffer with pH 2.8 enables UDCA to elute in its molecule form. Due to the low UV response of bile acids, the UV detector was set at $200 \mathrm{~nm}$ at which the studied molecules gave a satisfactory absorbance and representable chromatogram (Fig. 1b, St mix) (Boscolo et al., 2017).

All samples and standards were diluted in an acidified methanol with formic acid (methanoic acid), $\mathrm{pH}$ 3.0 of solution, in order to ensure the molecular forms of UDCA and related substance.

Dwell volume is important parameter for gradient elution, because of its greatest effect on retention times of substances that are not strongly retained. Dwell volume (0.57) was calculated according to the recommendation of the European pharmacopeia (Ph. Eur., 2.2.46), which means the proposed linear gradient elution is suitable. In 


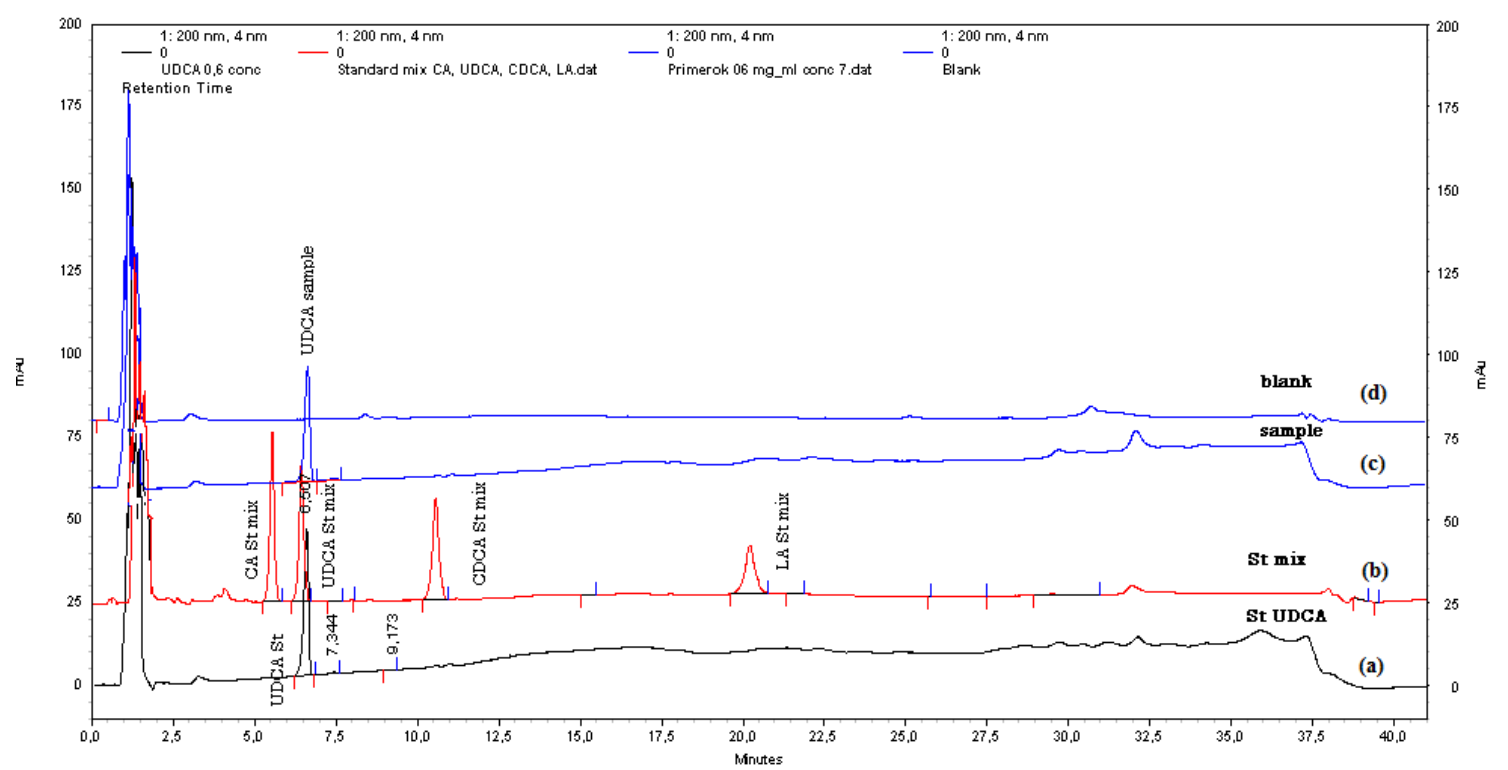

Fig. 1. Typical chromatograms of: (a) ursodeoxycholic acid standard solution; (b) ursodeoxycholic acid standard mix solution of UDCA and related bile acids, CDCA, CA and LA; (c) ursodeoxycholic acid capsule $150 \mathrm{mg}$ sample solution; (d) blank solution.

order to achieve good peak shape, symmetry, and the highest resolution of UDCA and its related impurities, the flow rate was set at $1.5 \mathrm{~mL} \mathrm{~min}^{-1}$ and HPLC injection volumes were $50 \mu \mathrm{L}$.

UDCA was identified based on the retention time as compared with the UDCA standard. As shown in the chromatogram, the method is capable of separating UDCA in the presence of the related impurities (Fig. 1b). Furthermore, with the proposed method we obtained a comparable sensitivity (with suitable limit of detection (LoD) of $0.099 \mu \mathrm{g} \mathrm{mL}^{-1}$ and limit of quantification (LoQ) of $0.303 \mu \mathrm{g} \mathrm{mL}^{-1}$ ) with the sensitivity obtained in the published HPLC methods coupled to refractive index detector (Varinder et al., 2015b).

\section{Method validation}

Method validation was performed following the $\mathrm{ICH}$ Harmonized Tripartite Guideline; Validation of Analytical Procedures: Text and MethodologyQ2(R1) (ICH, 2005).

\section{System suitability}

The most important SST (system suitability) parameters which are investigated for HPLC analyses are: resolution $(\mathrm{R})$, repeatability or reproducibility (relative standard deviations (RSD) of peak response and retention time), column efficiency or plate count $(\mathrm{N})$ and tailing factor (T) (Bose, 2014).

The system suitability parameters were calculated according to the recommendation of the United States Pharmacopoeia and reported as RSD of peak response and retention time (USP, $\langle 1225\rangle$; <621>).

We assessed the system repeatability by 6 consecutive injections of standard UDCA solution with concentration of $0.6 \mathrm{mg} \mathrm{mL}^{-1}$.

The relative standard deviations $(\mathrm{RSDs}=0.38 \%$ ) of the UDCA peak area of standard and resolution solutions satisfy the acceptance criteria (Fig. 1b). Furthermore, the proposed method was found to be suitable in terms of efficiency (10835.16); tailing factor (0.96) and resolution (4.40) between UDCA (as main peak) and CA (its closest peak) according to USP (<621>). Relative retention time (RRT) also known as the "unadjusted relative retention" is defined as the ratio of the retention times of any component to the retention times of reference compound.

Relative retention times (RRT) in relation to UDCA (Fig. 1b) were found to be: RRT is 0.7 for CA (Rt CA = $4.752 \mathrm{~min}$ ), RRT is 1.5 for CDCA ( $\mathrm{Rt} \mathrm{CDCA}=9.771$ $\mathrm{min}$ ) and RRT is 3.0 for LA (Rt LA = $19.408 \mathrm{~min}$ ) according to USP $(<621>)$.

\section{Specificity and selectivity}

Specificity ensures the identity of an analyte of interest. It is demonstrated by the ability to discriminate between compounds of closely related structures, or by comparison to known reference materials. The specificity of the HPLC method was accomplished with the complete separation of UDCA in the presence of related bile acids and excipients used to formulate and produce these hard capsules. In addition, there was not any interference observed at the retention time of UDCA in the chromatogram of blank solution (Fig. 1). 
Peak purity of the sample solution was higher than $99.8 \%$, demonstrating that other compounds did not coelute with peak of interest.

\section{Linearity and range}

Linearity was determined in the range of $0.12-1.05$ $\mathrm{mg} \mathrm{mL}^{-1}$ for UDCA. The correlation coefficient (r) observed was 0.9999. Typically, the regression equation for the calibration curve was found to be $740023 \mathrm{x}+$ 2104.5, with standard errors of intercept 1665.2 and slope 2680.5 .

The results of the regression statistics indicate that the method is linear over the concentration range studied.

\section{Precision and Accuracy}

Precision was evaluated in terms of repeatability and intermediate precision. Repeatability was assessed using six separate sample solutions at $100 \%$ of the test concentration $\left(0.6 \mathrm{mg} \mathrm{mL} \mathrm{mL}^{-1}\right.$ UDCA) on the same equipment and on the same day.

The intermediate precision was calculated using six sample solutions, prepared at the same conditions, over three consecutive days. The RSD values were calculated from the retention time and peak areas, respectively of UDCA of the series of measurements (Sheng et al., 2018).

The variation in the results obtained for UDCA determination within a day (intra-assay precision) $(\mathrm{RSD}=$ $0.58 \%$ and $\mathrm{RSD}=0.37 \%$, of retention time and peak area, respectively) and day to day variations (intermediate precision) $(\mathrm{RSD}=0.27 \%$ and $\mathrm{RSD}=0.16 \%$, of retention time and peak area, respectively) was very low $(\leq 2 \%)$, thus confirming the precision of the method.

The accuracy of the HPLC analysis was determined by spike recovery. To discover whether excipients interfered with the analyte, sample solutions were spiked with different known amounts of UDCA standard solution $(25 \%, 50 \%, 75 \%, 100 \%, 125 \%$ and $150 \%)$. The percent of recovery was calculated using the calibration equation.

Recovery values (Table 1) obtained from the determination of UDCA in commercial hard capsules using the method of standard additions confirmed that the method was accurate and precise in the range of $25-150 \%$ of the working concentration.

\section{Limit of detection and limit of quantitation}

LoQ and LoD were determined to evaluate the sensitivity of the proposed method. LoD (also called detection limit) is defined as the smallest amount or concentration of analyte in the test sample that can be reliably distinguished from zero, while LoQ is defined as the lowest concentration of analyte that can be determined with an acceptable repeatability and trueness under the stated operational conditions of the method.

In order to access LoD and LoQ, UDCA standard solutions were diluted to obtain lower concentrations in a range of $0.289 \mu \mathrm{g} \mathrm{mL}^{-1}$ to $25.023 \mu \mathrm{g} \mathrm{mL}^{-1}$ and injected onto the chromatographic system.

LoD and LoQ were calculated with regression statistical analysis of the calibration curve obtained with the low concentrations of UDCA, using the ratio 3.3 SD/S and $10 \mathrm{SD} / \mathrm{S}$ respectively, where SD is standard deviation of the response based on the standard deviation of $y$ intercepts of regression lines and $\mathrm{S}$ is slope of the calibration curve (ICH, 2005).

The LoD and LoQ for UDCA were $0.099 \mu \mathrm{g} \mathrm{mL}{ }^{-1}$ (99 $\mathrm{ng} \mathrm{mL} \mathrm{mL}^{-1}$ ) and $0.303 \mu \mathrm{g} \mathrm{mL} \mathrm{mL}^{-1}\left(303 \mathrm{ng} \mathrm{mL}^{-1}\right.$ ), respectively.

Table 1. Accuracy of the method (The data obtained from accuracy testing of method)

\begin{tabular}{|c|c|c|c|c|c|}
\hline $\begin{array}{c}\text { Amount } \\
\text { added }^{1} \\
\left(\mathrm{mg} \mathrm{mL}^{-1}\right)\end{array}$ & $\begin{array}{c}\text { Amount } \\
\text { found }^{2} \\
\left(\mathrm{mg} \mathrm{mL}^{-1}\right)\end{array}$ & $\begin{array}{c}\text { Recovery } \\
(\%)\end{array}$ & $\begin{array}{l}\text { C.I }^{3} \\
(\%)\end{array}$ & $\begin{array}{c}\text { RSD } \\
(\%)\end{array}$ & $\begin{array}{l}\text { Bias } \\
(\%)\end{array}$ \\
\hline 0.150 & 0.154 & 102.71 & $101.96-103.45$ & 0.29 & 2.71 \\
\hline 0.300 & 0.305 & 101.77 & $100.24-103.29$ & 0.61 & 1.77 \\
\hline 0.450 & 0.463 & 102.85 & $100.92-104.77$ & 0.75 & 2.85 \\
\hline 0.600 & 0.607 & 101.15 & $99.36-102.94$ & 0.71 & 1.15 \\
\hline 0.750 & 0.753 & 100.34 & $99.05-101.62$ & 0.52 & 0.34 \\
\hline 0.900 & 0.898 & 99.82 & $98.06-100.91$ & 0.58 & $-0,18$ \\
\hline & & 101.44 & $100.14-102.74$ & 0.58 & 1.44 \\
\hline
\end{tabular}

\footnotetext{
${ }^{1}$ Mean value ( $\mathrm{n}=3$ ) of amount added of UDCA standard solution to sample solutions with working concentration $0.6 \mathrm{mg} \mathrm{mL}^{-1}$

${ }^{2}$ Mean value ( $\mathrm{n}=3$ ) of amount found of UDCA standard solution in sample solutions with working concentration $0.6 \mathrm{mg} \mathrm{mL}^{-1}$

${ }^{3} 95.0 \%$ Level of confidence
} 


\section{Robustness}

Robustness which is a definition for the capacity of a method is a measure of the reliability of a method. Robustness of the method was investigated by varying the instrumental conditions such as variations in the $\mathrm{pH}$ of mobile phase $( \pm 0.2)$, column temperature $\left( \pm 5{ }^{\circ} \mathrm{C}\right)$, while maintaining the same operational and environmental conditions. The obtained values for tailing factor were within the acceptable limits $(<2)$, as well as the obtained standard deviations of the retention time of main peak $(\leq$ $1.5 \%$ ) were found to be in the acceptable range (USP, $<621>$ ). The results show that the small and deliberate variations in the column temperature, and $\mathrm{pH}$ of mobile phase, do not affect the robustness of the system.

\section{Conclusion}

The validated method was applied for determination of UDCA in commercially available hard capsules containing $150 \mathrm{mg}$ UDCA. The results obtained indicate that the proposed RP-HPLC method with UV detection was found to be specific, sensitive, accurate, precise and robust for determination of UDCA in pharmaceutical dosage forms.

Furthermore, results from LoD and LoQ, and the chromatogram obtained from standard mix solution (Fig. 1b) illustrates an acceptable resolution between UDCA and $\mathrm{CA}$ as closest eluted peaks and demonstrated that the proposed method is capable to separate and to accurately determine the active substance UDCA in the presence of related bile acids (CA, CDCA and LA) and eventually present unknown impurities.

\section{References}

Boscolo, O., Flor, S., Dobrecky, C., Salvo, L., Tripodi, V., Lucangioli, S., 2017. Development and validation of a LCUV method applied to the quality control of ursodeoxycholic acid in raw material and pharmaceutical formulations. IOSR Journal of Pharmacy 7(2), 111-116. Available at: https://doi.org/10.9790/3013-070201111116.

Bose, A., 2014. HPLC calibration process parameters in terms of system suitability test. Austin Chromatography 1(2), 1-4.

Courillon, F., Gerhardt, M.F., Myara, A., Rocchiccioli, F., Trivin, F., 1997. The optimized use of gas chromatographymass spectrometry and high performance liquid chromatography to analyse the serum bile acids of patients with metabolic cholestasis and peroxisomal disorders. Clinical Chemistry and Laboratory Medicine 35(12), 919922. Available at: https://doi.org/10.1515/cclm.1997.35.12.919.

European Pharmacopoeia, Ninth Edition, Supplement 9.8, 2019. European directorate for quality of medicines, Council of
Europe, Strasbourg, France.

International Conference on Harmonization of Technical Requirements for Registration of Pharmaceuticals for Human Use, 2005. ICH Harmonized Tripartite Guideline: Validation of Analytical Procedures: Text and Methodology Q2(R2).

Mas, M.R., Comert, B., Mas, N., Yamanel, L., Ozotuk, H., Tasci, I., Jazrawi, R.P., 2007. Effects of long term hydrophilic bile acid therapy on in vitro contraction of gallbladder muscle strips in patients with cholesterol gallstones. World Journal of Gastroenterology 13(32), 4336. Available at: https://doi.org/10.3748/wjg.v13.i32.4336.

Qiao, X., Ye, M., Liu, C.F., Yang, W.Z., Miao, W.J., Dong, J., Guo, D.A., 2012. A tandem mass spectrometric study of bile acids: interpretation of fragmentation pathways and differentiation of steroid isomers. Steroids 77(3), 204-211. Available at: https://doi.org/10.1016/j.steroids.2011.11.008.

Raghunadha Reddy, S., 2010. Quantification of Ursodeoxy Cholic acid in human plasma by using High performance liquid chromatography-tandem mass spectrometric method and its applications in pharmacokinetics. Journal of Chemical and Pharmaceutical Research 2(3), 59-69.

Roda, A., Gioacchini, A.M., Manetta, A.C., Cerre, C., Montagnani, M., Fini, A., 1995. Bile acids: physicochemical properties, function and activity. The Italian journal of gastroenterology 27(6), 327.

Roda, A., Cerre, C., Simoni, P., Polimeni, C., Vaccari, C., Pistillo, A., 1992. Determination of free and amidated bile acids by high-performance liquid chromatography with evaporative light-scattering mass detection. Journal of lipid research 33(9), 1393-1402.

Rodríguez, V.G., Lucangioli, S.E., Otero, G.C.F. and Carducci, C.N., 2000. Determination of bile acids in pharmaceutical formulations using micellar electrokinetic chromatography. Journal of pharmaceutical and biomedical analysis 23(2-3), 375-381. Available at: https://doi.org/10.1016/S07317085(00)00314-9.

Sheng, Z., Ye, R., Ge, S., Wang, C., Xu, X., Zhang, G., Luo, P., 2018. A validated RP-HPLC method for quantitative determination of related impurities of cholic acid bulk drugs. Acta Chromatographica 30(2), 114-118. Available at: https://doi.org/10.1556/1326.2017.00250.

Stamp, D. and Jenkins, G., 2008. An overview of bile-acid synthesis, chemistry and function. Bile acids: toxicology and bioactivity. Cambridge, UK: Royal Society of Chemistry, 1-13. Available at: https://doi.org/10.1039/9781847558336-00001.

United States of Pharmacopoeia 42-NF37, 2019. Rockville MD, USA: United States Pharmacopeia Convention, Inc.

U.S. Food and Drug Administration, Center for Drug Evaluation and Research. 1994. Reviewer Guidance, Validation of Chromatographic Methods; FDA, Rockville.

Varinder, S., Kumar, P., Gurjeet, S., Shah, G., Dhawan, R.K., 2015. Analytical method development and validation for the estimation of ursodeoxycholic acid using RP-HPLC. Journal of Pharmacy Research 9(1), 46-53. Available at: https://doi.org/10.1055/a-1141-3475. 


\title{
Резиме
}

\section{Валидиран RP-HPLC метод со УВ детекција за определување на урсодеоксихолна киселина во фармацевтски формулации}

\author{
Жаклина Попоска Свиркова ${ }^{1 *}$, Зорица Арсова-Сарафиновска ${ }^{1}$, \\ Александра Грозданова ${ }^{2}$ \\ ${ }^{1}$ Институт за јавно здравје на Република Северна Македонија, 50та Дивизија бр.6, \\ 1000 Скопје, Република Северна Македонија \\ ${ }^{2}$ Институт за фармацевтска хемија, Фармацевтски Факултет, \\ Универзитет „Св. Кирил и Методиј”, Мајка Тереза 47, \\ 1000 Скопје, Република Северна Македонија
}

Клучни зборови: урсодеоксихолна киселина, HPLC/UV, фармацевтски дозирани форми, валидација на метод

Поради ниската апсорпција на жолчните киселини, имавме за цел да се развие и валидира едноставен и чувствителен HPLC/UV метод за определување на урсодеоксихолна киселина (UDCA) во фармацевтски производи. Ефективно раздвојување се постигна на С18 „еnd-capped” колона, со градиентно елуирање на мобилната фаза составена од мешавина на 0,001 M фосфатен пуфер (pH 2,8 $\pm 0,5)$ и ацетонитрил, со проток $1,5 \mathrm{~mL}$ $\min ^{-1}$, UV детекција на $200 \mathrm{~nm}$ и волумен на инјектирање $50 \mu \mathrm{L}$. Предложениот HPLC/UV метод беше целосно валидиран според упатствата на ICH и беше потврдено дека истиот е едноставен, точен, прецизен и робустен. 